\title{
Glasbeno-analitični nastavki: med idejo in strukturo
}

$\mathrm{V}$ nalogi je podan prerez pojma analiza s teoretičnega, danes vse bolj aktualnega stališča (raz)umevanja glasbenega stavka v smislu zgodovinsko pogojenega sistema simbolov. Kot pomemben pojem glasbene nomenklature, katerega so posamezni avtorji - kot pričajo ohranjeni viri - oblikovali v skladu s vsakokratnimi "teoretičnimi" ("the verb theoreo, meaning to inspect, look at, behold, observe, contemplate, consider") ${ }^{1}$ predpostavkami, je tako tudi analiza predstavljena kot pojem, ki ga je težko "izolirati" od procesa spreminjanja pomena tonskih pojavov. Prerez pojma analiza torej kronološko zasleduje tista teoretična kompozicijskoanalitična izhodišča ali "nastavke" - avtor je prepričan, da je možno prispevati k poglobljenejšemu (raz)umevanju današnje "analitične mrzlice" predvsem s študijem zgodovinskih premen pomena pojma analiza, kar izkazujejo posamezna obdobja -, ki jih zgodovinopisje prišteva v kanon nauka o glasbi. Gradivo raziskovanja tako izhaja iz pričevanj pomembnejših piscev, katerih refleksije o tonskem stavku, pomenu, ki so mu ga pripisovali, in konotacij, ki so nanj vezane, današnja literatura umeva kot vplivne izkaze pojmovanja tonskih pojavov.

Vzgib za zastavljeno nalogo?

Analiza tonskega stavka $\mathrm{v}$ današnjem pomenu sodi med tiste teoretične panoge, ki se ukvarjajo predvsem z zgrajenostjo glasbenega stavka, in je kot eden od predmetov muzikologije zakoličena tako rekoč $\mathrm{v}$ relativno mladi predočbi, katere izhodišče bi lahko označili kot: t.i. "formalistični koncept". Vsekakor upravičeno in docela legitimno vztrajanje na tem, da bistvo glasbenega predstavlja notni zapis

1 The New Grove Dictionary of Music and Musicians, ur. Stanley Sadie, London 1980, geslo Theory, theorists, 741. 
per se, pa - na današnji ravni stroke, ki si prizadeva v svoj delokrog vključiti na prvi pogled "zunaj-glasbene" dejavnike, ki so nepogrešljivi za (raz)umevanje "čisto-glasbenih" dejstev - ne zadovolji kriterijev celostnejšega umevanja zastavljene teme. Vključitev nekaterih poglavij, ki so pomembna predvsem za širši teoretični kontekst, $v$ katerega je vpet pojem analiza in brez katerega je težko razumeti njeno vlogo - bodi v splošni pedagogiji, bodi v razmerju do drugih predmetov, ki jih obsega študij glasbe - sicer presega okvir analize glasbe in se navezuje na vrsto estetskih, psiholoških, filozofskih ali teoretičnih postavk, ki pa so sestavni del toposa o analizi v glasbi.

Izhajam iz definicije pojma analiza v leksiki in vprašanj, vezanih na njegovo področje, ki se preklaplja tako s praktičnim naukom o kompoziciji kot njegovimi estetskimi in poetičnimi postavkami. Skušam slediti premisi, po kateri je tonski stavek - bodi kot nauk o kompoziciji, bodi v okviru glasbene recepcije - vezan pravzaprav na vzporejanja ali analogije glasbenega gradiva z "zunaj-glasbenimi" vodili kot sta (1) za glasbo do približno 18. stoletja najpomembnejši: platonističnopitagorejski nauk o "naravnih" proporcih ali glasbeni aritmetiki in (2) vzporejanje glasbenega ustroja $\mathrm{z}$ ustrojem jezika (glasbena gramatika, glasbena retorika). Do sredine 18. stoletja, kot rečeno, analizo narekujeta predvsem dve področji: vzporejanje tonskih zakonitosti z zakonitostmi, po eni plati, pitagorejske aritmetike in, po drugi, jezikovne oz. stavčne logike. Na področje o stavčni logiki sodi koncept glasbene retorike, $v$ katerem je vse pomembnejši pomen posameznega pojma in ne le sintaktične zasnove besedila. Te kompozicijske principe je sicer treba med seboj razmejiti, vendar jih je nujno razumeti kot tri oblikotvorna vodila, ki se med seboj dopolnjujejo, čeprav posamezna obdobja poudarjajo enkrat "bolj-to", drugič "boljdrugo".

Tako sem, denimo, $v$ nadaljevanju sledil glasbeni aritmetiki $v$ antiki, čeprav še $v$ renesansi predstavlja eno od pomembnejših poglavij glasbene teorije, medtem ko sem v srednjem veku pozornost usmeril na glasbeno gramatiko - kljub temu, da pomen posaméznih pojmov, kar je poudarjala glasbena retorika, tvori obsežno poglavje tudi $\mathrm{v}$ času pred humanizmom. Vsak od teh treh kompozicijskih principov seveda predstavlja samostojno področje raziskovanja, kar ni predmet zastavljene naloge. $V$ nalogi skušam navedena kompozicijska načela opazovati s stališča (raz)umevanja zgrajenosti glasbenega stavka "po analogijah z...", torej s stališča koncepta posnemanja (mimesis), v katerem vidim eno od osnovnih gibal, stalnico, ki spremlja tako analizo, torej razumevanje glasbe, kot njeno področje kompozicijo - skozi vso zgodovino.

Oris pojma analiza, katerega so glasbeniki v različnih obdobjih različno utemeljevali, pač na podlagi tisti čas aktualne epistemološke opredelitve glasbe, je osrediščen $\mathrm{v}$ naslednjih poglavjih: 
1. Analiza, ki razkriva značilnosti tonskega sistema (systëma) praviloma po analogijah $z$ univerzalnimi aritmetičnimi proporci (canon monochordi), le-ti pa so podvrženi postulatom praktične filozofije - moralnemu nauku -, je značilna za pitagorejsko-platonistično tradicijo. (Prvotno se tovrstna analiza nanaša na teorijo, tako da obravnavano skladbo opazuje v smislu "pravilne" aplikacije določenih kompozicijsko-teoretičnih vodil v praksi.)

2. Analiza, ki razkriva značilnosti oblikovanja tonskega stavka po analogijah z ustrojem jezika. Po eni plati je zanjo merilo predvsem stavčni ustroj oz. skladna ureditev tonskega gradiva in jezikovne strukture, torej stavka ali povedi (glasbena gramatika). Vsaj od prvih srednjeveških traktatov o večglasju dalje (Musica in Scolica enchiriadis; druga polovica 9. stol.) in vsaj do baročnega nauka o figurah oz. afektih predstavlja glasbena gramatika osnovno vodilo opazovanja glasbenega stavka. 2.1. Analiza, ki razkriva značilnosti oblikovanja tonskega stavka po analogijah z ustrojem jezika, ob tem pa upošteva tudi pomen, smisel, konotacije, intence itn. posameznega pojma. Tovrstno analitično opazovanje se v kulturi vokalno-instrumentalne glasbe pravzaprav izmika natančni časovni zamejitvi, čeprav je topos o "ekspresivnosti" posameznega pojma $v$ teoretski refleksiji vse pogosteje izpričan od renesanse dalje, predvsem $\mathrm{v}$ zvezi $\mathrm{z}$ glasbeno retoriko, katere najbolj izčiščeno obliko izkazuje baročni nauk o afektih oz. figurah.

3. Analiza, ki razkriva značilnosti oblikovanja tonskega stavka predvsem na podlagi oblikovnih vzorcev; paradigma: klasicistična "periodologija" utemeljena na zgledih "uporabnih oblik" (H. C. Koch) - plesnih stavkov - in kasnejše oblikoslovje. Značilno klasicistično-romantično opazovanje tonske zgradbe izhaja iz kochovskega "mehanskega" dela kompozicijskega nauka, akustično (v alikvotni vrsti) utemeljenega - za razliko od antike, ki je tonski sistem utemeljevala aritmetično - umevanja tonske zgradbe na podlagi paradigme harmonskega mišljenja: kadence. Od konca 18. in v 19. stoletju je ob harmonskem vse pomembnejši tudi motivično-tematski ustroj, kar gre razumeti predvsem v smislu "der Umakzentuierung des Formsinns"', ki ga izkazuje krovni kompozicijsko-analitični koncept instrumentalne glasbe od konca 18. stoletja, koncept glasbene logike. Če je namreč J. N. Forkel 1. 1788 z glasbeno logiko označil predvsem načela harmonske gradnje, se je v 19. stoletju pojem nanašal v prvi vrsti na motivično in tematsko mrežo v skladbi. Ravno v konceptu glasbene logike so glasbeniki dobili kompozicijsko-analitično kategorijo, ki je omogočila refleksije o pomenu tonskih konstelacij brez analogij z jezikovno zgradbo (glasbena gramatika), pomenom pojmov (glasbena retorika) ali aritmetičnimi proporci. Tonska struktura naj se torej ne bi ravnala po "zunajglasbenih" analogijah, temveč naj bi se generirala po imanentnih, "čisto, absolutno glasbenih" vodilih, za katera pa se zdi - kar posrečeno 
izkazujejo prizadevanja t.i. "energetikov" in "strukturalistov" -, da se pravzaprav nikoli niso mogla izogniti "zunajglasbenim" analogijam. (Primer: Schenkerjeva analitična teorija.) Nasprotno: $v$ analitičnih teorijah 20. stoletja ponujene analitične kategorije izhajajo iz "univerzalizirajoče" nomenklature fizike, matematike in lingvističnega strukturalizma.

Obranjeno 16. oktobra 1997 na Filozofski fakulteti v Ljubljani. 


\section{Musico-Analytic Points of Departure: Between Idea and Structure}

The thesis brings a cross section of the concept analysis from the increasingly topical viewpoint of understanding the compositional structure in terms of a bistorically determined set of symbols. As an important concept in musical nomenclature, which individual authors - as it is clear from the sources preserved-have shaped in accordance with "theoretical" ("the verb theoreo, meaning to inspect, look at, bebold, observe, contemplate, consider") ${ }^{1}$ assumptions of the time, analysis is likewise presented as a concept hard to "isolate" from the process of changing the meaning of tonal phenomena. The cross section of the concept analysis, therefore, chronologically traces those theoretic compositional-analytical starting points or "points of departure" - the author feels sure that a contribution towards a fuller understanding of the present "analytic fever" is possible above all through a study of bistorical shifts in the meaning of the concept "analysis", as exbibited by particular periods which are in historiography inberent in the canon of musical scholarship. The research material is thus based on evidence handed down by the more important authors, whose reflections on the tonal structure and significance attributed to it and connotations related to it, are in current literature appreciated as influential indeces for the comprehension of tonal phenomena.

What stimulated the task in question?

The analysis of the tonal composition in the current sense of the term belongs among those theoretical fields which deal predominantly with the structure of the musical composition and is as one of the subjects of musicology implanted in the relative young idea, the origin of which could be characterized as: the so-called "formalistic concept". At any rate the justifiable and perfectly legitimate insistence on the fact that the essence of what is musical is represented by the musical notation per se cannot - at the present level of the discipline which strives to include within its range of activities seemingly "extra-musical" factors that are indispensable for an understanding of "pure-musical" facts - meet the criteria of a more comprebensive understanding of the theme in question. The inclusion of some chapters, significant above all for the broader theoretical context harnessed into which is the concept of analysis and without which it is difficult to understand its role - either in general pedagogy or in relation to other subjects contained in musical studies - otherwise reaches beyond the framework of musical analysis and relates to a series of aesthetic, psychological, philosophic, or theoretical items, which, bowever, are a constituent part of the work about analysis in music.

1 The New Grove Dictionary of Music and Musicians, ed. Stanley Sadie, London, 1980, heading Theory, theorists, 741. 
I proceed from the definition of the concept of analysis in lexica and from questions related to its field, which switches over to both practical lessons in composition and to its aesthetic and poetic items. I seek to follow the premise, claiming that the tonal structure - either as the theory of composition or within the framework of musical reception - is in fact bound up with drawing parallels and analogies of the musical material with "extra-musical" means such as are (1) for the music up to approximately the 18th century the most important ones: the Platonist-Pythagorean teaching about "natural" proportions or musical arithmetic, and (2) seeking correspondence between musical structure and the structure of language (musical grammar, musical rhetoric). Until the middle of the 18th century, as pointed out, the analysis is determined above all by two spheres: the matching of tonal rules with the rules, on the one hand, of the Pythagorean arithmetic, and, on the other, by those of the language logic, or rather of logic of seniences. Into the latter sphere belongs the concept of musical rhetoric, in which the meaning of the individual concept is becoming increasingly important and not just the syntactic scheme of the text. Whereas these compositional principles bave to be delimited one from another, they must necessarily be taken as three morphological guide-lines which are mutually complementary even if particular periods at one time stress "more this point" and at another "more the other point".

In this sense, let us say, I followed in the continuation the musical arithmetic in the Ancient Period, even if still in the Renaissance it represents one of the more important chapters of musical theory, whereas in the Middle Ages attention has been focused on musical grammar - despite the fact that the meaning of individual concepts, what was emphasized in musical rhetoric, represents an extensive chapter also at the time prior to Humanism. Each of the three compositional principles is understandably an independent area of research, this being not the subject of the task in question. In my thesis an attempt is made to study the compositional principles from the viewpoint of understanding the structure of the musical composition "in analogies with...", hence from the viewpoint of the concept of imitation (mimesis), in which I see one of the basic motive powers, as a constant accompanying both the analysis, bence the understanding of music, as its sphere - composition throughout bistory.

The outline of the concept analysis, which was by musicians in various periods variously substantiated, clearly on the basis of currently epistemologic definition of music, is focused upon in the following chapters:

1. The analysis which reveals the characteristics of the tonal system (systëma) as a rule by analogies with universal arithmetic proportions (canon monochordi), and these are subject to the postulates of practical philosophy - the moral teaching - is characteristic for the Pythagorean-Platonist tradition. (Originally this kind of analysis refers to the theory in the sense that the composition under discussion is 
evaluated in terms of a "correct" application of certain compositional-technical guide-lines in practice.)

2. The analysis which reveals the charcteristics of the tonal movement by analogies with the structure of language. On the one hand the criterion is here above all the structure of the movement or rather the harmonious ordering of tonal material and of the language structure, bence of the sentence or the minimal unit of communication (musical grammar). At least from the first mediaeval treatises on multi-part structure (Musica and Scolica enchiriadis; second balf of the 9th century) and at least to the baroque teaching about figures the musical grammar represents the fundamental guide-line for evaluating the musical composition.

2.1. The analysis which reveals the characteristics of the shaping of tonal structure by analogies with the structure of language, and in doing this takes into account also the meaning, sense, connotations, intentions, etc. of the particular concept. This kind of analytic evaluation in the culture of vocal-istrumental music in fact evades the exact marking-off of time, although the area of the "expressiveness" of a particular concept is in the theoretic reflection increasingly frequently found from Renaissance onwards, particularly in connection with musical rhetoric, the most purified form of which is to be seen in the baroque learning about affects, or rather about figures.

3. The analysis which reveals the characteristics of the shaping of tonal structure on the basis of formal patterns: paradigm, clasiccist "taxonomy" founded on examples of "applied forms" (H.C. Koch) - of dance movements - and subsequent morphology. The characteristic classicist-romantic evaluation of the tonal structure proceeds from Kochian "mechanic" part of the compositional learning, acoustically (in aliquot line) substantiated - in contradistinction to the Ancient Period where the tonal system was substantiated aritbmetically - understanding of the tonal structure on the basis of the paradigm of harmonic thought: cadence. Since the end of the 18th and in the 19th century along with the harmonic structure there grows increasingly in significance also the motivic-harmonic structure, which should be understood primarily in terms of "der Umakzentuirung des Formsinns", which is demonstrated by the parent compositional-analytic concept of instrumental music since the end of the 19th century, the concept of musical logic. For if J.N. Forkel in the year 1788 designated with musical logic above all the principles of harmonic structure, in the 19th century this concept was applied in the first place to the motivic and thematic network of the composition. It is precisely in the concept of musical logic that musicians have obtained the compositional-analytic category which made reflections about the meaning of tonal constellations possible without analogies with language structure (musical grammar), without meanings of concepts 


\section{MUZIKOLOŠKI ZBORNIK • MUSICOLOGICAL ANNUAL XXXIV}

(musical rhetoric) or without arithmetic proportions. Tonal structure should accordingly not be guided by "extra-musical" analogies, but should be generated by immanent "purely, absolutely musical" guide-lines, for which it seems - as is felicitously to be seen from the endeavours of the so-called "energetics" and "structuralists" - that actually they could never avoid "extra-musical" analogies. (An example: Schenker's analytical theory.) On the contrary: in the analytical theories of the 20th century the analytical categories proposed proceed from the "universalizing" nomenclature of physics, mathematics, and linguistic structuralism.

Defended on October 16, 1997, Philosopbical Faculty, Ljubljana. 